\title{
PESAN SEMIOTIKA DI BUNGKUS ROKOK DAN PENGARUHNYA PADA PEROKOK AKTIF
}

\author{
Anhar Fazri \\ Zainal Abidin \\ Jurusan Ilmu Komunikasi Fakultas Ilmu Sosial Dan Politik Universitas Teuku Umar \\ Email: faj_del06@yahoo.com
}

\begin{abstract}
This article discusses the existing semiotic messages on cigarette packs and the impact on active smoking, with research taking place in the Village of Alue Tho Seunagan District of Nagan Raya. The goal is to get the extent of the effectiveness or the effect of the semiotic messages and the number of public awareness to reduce the level of smoking addiction. in writing this article using descriptive quantitative research method is a method that discusses the current state based on data and research analysis. The data collection technique used observation and questionnaires to the respondent sample collection techniques using random sampling (random selection) is the whole object of the total population sampled 30 people ie $10 \%$ of the total population of 300 people, special people active smokers. These results can be seen the impact of the influence of semiotics messages through images on every cigarette packaging $60 \%$ affected from the entire informant, and $40 \%$ are not affected. The conclusion of the affected would have to consider the effect or stop smoking, then that is not affected by the effects do not exist. The effect influence the attitudes, behaviors and actions. It signifies the process of delivering the message conveyed properly. From the results of the most active smokers get the effect will be to change attitudes and views on smoking.
\end{abstract}

Keywords: Messages, Semiotic and Cigarette Packs.

\section{PENDAHULUAN}

Artikel ini membahas tentang pesan semiotika yang ada pada kemasan rokok dan pengaruhnya terhadap perokok aktif, dengan mengambil tempat penelitian di Gampong Alue Tho Kecamatan Seunagan Kabupaten Nagan Raya. Untuk melihat sejauhmana efektifitas pengaruh yang ditimbulkan akibat pesan yang disampaikan melalui bungkus rokok tersebut. Rokok adalah silinder kertas yang berisi Daun-daun Tembakau yang telah dicacah.

Tingkat kecanduan rokok semakin meningkat khususnya di Aceh bukan hanya pada kalangan dewasa, namun jugaterjadi pada remaja dan anak-anak sekolah mencoba menghisap rokok, sehinggga mereka akan menjadi perokok aktif, dan menyebabkan ketergantungan terhadap zat nikotin tersebut. Meskipun mereka tahu pada kemasan rokok terdapat gambar peringatan disertai penyakit yang ditimbulkan akibat merokok,namun kesadaran bahaya merokok tersebut tidak membuat para perokok memutuskan untuk berhenti merokok. Faktor kecanduan nikotin pun turut mempengaruhi terganggunya rasionalitas para perokok tersebut.

Rokok dibakar pada salah satu ujungnya dan dibiarkan membara untuk dihisap asapnya lewat mulut pada ujung lainnya. penghisapan asap rokok yang biasa dilakukan oleh pecandu 
rokok, perokok aktif adalah orang yang menghisap asap rokoknya sendiri. ${ }^{1}$ Rokok sangat berbahaya bagi kesehatan bagi perokok maupun orang disekitarnya. Menurut hasil penelitian oleh King's College London merokok bisa "membusukkan" otak dengan merusak memori, kemampuaan belajar dan daya nalar. Subjek penelitian dilakukan terhadap 8.800 orang dengan rentan usia berkisar 50 tahun keatas yang mengalami tekanan darah tinggi dan kelebihan berat badan. $^{2}$

Untuk itu pemerintah mengeluarkan peraturan pada tangal 10 Maret 2003, pemerintah mengeluarkan PP No.19/2003 tentang pengamanan rokok bagi kesehatan yang didalamnya tercantum peraturan-peraturan yang harus dipatuhioleh produsen rokok. Pada bagian ketiga tentang keterangan pada label tercantum indikator-indikator apa saja yang harus dipenuhi untuk membuat label peringatan bahaya merokok sehingga legal untuk dipasarkan. ${ }^{3}$

Pada kemasan rokok sekarang ini menampilkan gambar yang merupakan pesan yang disampaikan lewat pesan semiotika, yaitu penyampaian pesan tersebut disampaikan dengan kode dan tanda yang memiliki makna untuk disampaikan. Tujuannya agar masyarakat memahami bahaya yang diakibatkan dari zat nikotin yang terdapat pada rokok yang akan menimbulkan berbagai macam penyakit dan membahayakan kesehatan tubuh.

Semiotika komunikasi memfokuskan pada teori tentang produksi tanda yang salah satunya diantaranya mengasumsikan adanya enam faktor dalam komunikasi, yaitu pengirim, penerima kode, pesan, saluran komunikasi dan acuan terhadap hal yang dibicarakan serta memberikan tekanan pada teori tanda dan pemahamannya dalam suatu konteks tertentu. ${ }^{4}$

Semua peringatan bergambar dianggap lebih efektif dari peringatan teks secara tertulis di pesan terkait dan variabel dampak terkait, termasuk niat untuk berhenti atau tidak mulai merokok di kalangan masyarakat. Sedangkan gambar peringatan kesehatan pada kemasan juga tetap tidak mempengaruhi konsumen rokok untuk berhenti merokok, para konsumen rokok ini beranggapan bahwasannya merokok itu tidak akan mengalami sakit seperti dalam halnya pada gambar kemasan yang ada ditiap-tiap bungkus rokok

Upaya untuk menyadarkan para perokok untuk meninggalkan kebiasaan merokok memang tidaklah mudah. Banyak yang telah dilakukan, mulai dari kampanye bahaya rokok bagi kesehatan hingga penerapan aturan tentang pencantuman peringatan tertulis dikemasan. Meskipun banyak sekali dampak yang membahayakan bagi pecandu rokok akan tetapi para pecandu rokok tidak jera, padahal pada kemasan rokok sudah disebutkan bahwa merokok dapat menimbulkan berbagai macam penyakit bahkan dapat memyebabkan kematian.

\section{LANDASAN TEORITIS}

Pengertian Pesan Semiotika

Semiotika berasal dari kata Yunani yang berarti tanda. Dalam pandangan Piliang, penjelajahan semiotika sebagai metode kajian kedalam berbagai cabang keilmuan ini yang dimungkinkan karena ada kecenderunga untuk memandang berbagai wacana sosial sebagai fenomena bahasa. Dengan kata lain, bahasa dijadikan model dalam berbagai wacana sosial. Berdasarkan pandangan semiotika bila seluruh praktik sosial dapat dianggap sebagai fenomena bahasa, maka semuanya dapat dipandang sebagai tanda. Hal ini dapat dimungkinkan karena

${ }^{1}$ Sutiono Supinto, Cegah Dini Kanker dan Tumor, (Jakarta:.Sunda Kelapa Pustaka.2008), h. 16.

2 Jaya Muhammad, Pembunuh Berbahaya Itu Bernama Rokok, (Jakarta:Rizma', 2009), h. 89

${ }^{3}$ Pp_No._19_Th_2003. http://www.litbang.depkes.go.id. Diakses 5 Februari 2017.

4 Bambang Mudjiyanto, Semiotika Dalam Metode Penelitian Komunikasi Semiotic, (Makassar:Balai Besar Pengkajian dan Pengembangan Komunikasi dan Informatika, 2013),h. 56 
luasnya pengertian tanda itu sendiri. ${ }^{5}$

Para ahli yang terkemuka dalam ilmu semiotika ada dua yaitu Ferdinand De Saussure (1857-1913) dan Charles Sander Peirce (1839-1914). Kedua tokoh tersebut mengembangkan ilmu semiotika secara terpisah dan tidak mengenal satu sama lain. Latar belakang Saussure adalah linguistik, sedangkan Peirce filsafat. Pendapat Saussure yang dikutip oleh Hidayat, semiotika adalah anggapan bahwa selama perbuatan dan tingkah laku manusia membawa makna atau selama berfungsi sebagai tanda, dibelakangnya harus ada sistem pembedaan dan onvensi yang memungkinkan makna itu. Dimana ada tanda, disana ada sistem. ${ }^{6}$

Menurut Pierce semiotika merupakan tanda yang dapat mewakili sesuatu yang lain dalam batas-batas tertentu. Tanda akan selalu mengacu ke sesuatu yang lain, tanda baru dapat berfungsi bila diinterpretasikan dalam benak penerima tanda melalui interpretant yang mengacu pada pemahaman makna yang muncul dalam diri penerima tanda. Artinya tanda baru dapat berfungsi jika tanda dapat ditangkap dan pemahaman terjadi berkat ground yaitu pengetahuan tentang sistem tanda dalam suatu masyarakat. ${ }^{7}$

Semiotika adalah ilmu yang mempelajari tanda. Tanda-tanda tersebut menyampaikan suatu informasi sehingga bersifat komunikatif. Ia mampu menggantikan sesuatu yang lain yang dapat difikirkan atau dibayangkan. Cabang ilmu ini semula berkembang dalam bidang bahasa, kemudian dikembangkan pula dalam bidang seni rupa dan desain komunikasi visual.

Tanda dalam kehidupan manusia bisa tanda gerak atau isyarat; lambaian tangan yang bisa diartikan memanggil atau anggukan kepala dapat diterjemahkan setuju. Kita hidup dan bermain dalam tanda bunyi, seperti tiupan peluit, terompet, genderang, suara manusia, atau dering telepon juga tanda tulsan, diantaranya huruf dan angka. Bisa juga tanda gambar berbentuk rambu lalu lintas, dan masih banyak lain ragamnya yang dapat memuat makna tertentu. $^{8}$

Pesan Semiotika Pada Perokok

Komunikasi terjadi dengan perantaraan tanda-tanda, dengan demikian sebagian teori komunikasi berasal dari semiotika. Teori komunikasi menaruh perhatian pada kondisi penyampaian signifikasi, yaitu pada saluran komunikasi. Berkat saluran komunikasi inilah pesan dapat tersampaikan.

Pesan semiotika yang disampaikan kepada perokok melalui tanda-tanda yang memilki makna tertentu. Pesan yang disampaikan tersebut berupa gambar yang ditempelkan pada setiap kemasan rokok.

Media verbal gambar merupakan media yang paling cepat untuk menanamkan pemahaman. Informasi bergambar lebih disukai dibandingkan dengan informasi tertulis karena menatap gambar jauh lebih mudah dan sederhana. Gambar berdiri sendiri, memiliki subjek yang mudah dipahami dan merupakan "simbol" yang jelas dan mudah dikenal. ${ }^{9}$

Indonesia mulai menerapkan peraturan ini sejak 24 Juni 2014. Diterapkan lima jenis gambar yang menempati 30\%-40\% kemasan rokok. Tiap satu bungkus rokok dimuat satu buah gambar. Gambar tersebut terdiri dari gambar kanker mulut, merokok dapat membunuhmu, kanker tenggorokan, bahaya merokok di dekat anak-anak dan kanker paru. Kelima gambar

${ }^{5}$ Sumbo Tinarbuko, Semiotika Komunikasi Visual, (Yogyakarta:Jalasutra, 2008), h. 11

6 Sumbo Tinarbuko, Memahami Tanda, Kode, Dan Makna Iklan Layanan Masyarakat, (Bandung:ITB Bandung, 1998), h. 87.

${ }^{7}$ Alex Sobur, Semiotika Komunikasi, (Bandung:PT Remaja Rosdakarya, 2004), h. 41.

${ }^{8}$ Winfriend Noth, Handbook Of Semiotic, dikutip oleh SumboTinarbuko (Indianapolis: Indiana University Press, 1995), h. 44

${ }^{9}$ Rachmat supriyono, Desain Komunikasi Visual, (Yogyakarta:Balai Pustaka, 2010), h. 131 
tersebut yaitu:

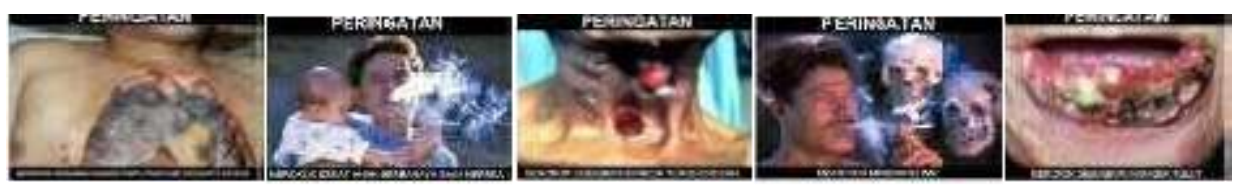

Gambar yang disampaikan lewat pesan semiotika.

\section{Pengaruh Pesan Semiotika Kepada Perokok}

Peringatan bahaya merokok telah diungkapkan pemerintah bersama warga masyarakat yang anti terhadap kegiatan merokok. Tapi dari himbauan itu tak ditanggapi secara serius oleh para perokok tersebut,mereka beranggapan bahwa peringatan itu hanya sebuah saran yang tak penting. Karena pemerintah hanya memberikan himbauan saja tanpa ada tindakan lebih lanjut mengenai aturan bagi perokok. Seperti yang dilakukan pemerintah saat ini telah memberlakukan disetiap kemasan rokok dibubuhi sebuah gambar peringatan bahaya merokok.

Gambar-gambar tersebut tampak sangat mengerikan, langkah ini diambil untuk menggantikan peringatan bahaya merokok yang terdahulu yang berupa tulisan. Sebaiknya pemerintah memberikan peraturan bagi perokok dengan memberikan sanksi yang tegas yang berupa denda maupun hukuman. Atau pemerintah memberikan solusi bagi perokok untuk mengurangi konsumsi rokok dengan melalui pengobatan bagi pecandu rokok berat.

Suatu desain kemasan yang menarik dibangun dari elemen visual dan elemen struktural yang didesain sedemikian rupa untuk menimbulkan suatu respon positif pada konsumennya. ${ }^{10}$ Elemen visual adalah bagian kemasan yang menarik perhatian konsumen pada saat melihat seperti warna kemasan, bentuk kemasan, dan desain grafis seperti ukuran, gambar dan slogan pada label kemasan. Sedangkan elemen struktural adalah bahan atau material yang digunakan pada kemasan.

Dalam psikologi, persepsi visual adalah kemampuan manusia untuk menginterpretasikan informasi yang ditangkap oleh mata. Hasil dari persepsi ini disebut sebagai penglihatan (eyesight, sight atau vision). Unsur- unsur ragam psikologi dalam penglihatan secara umum terangkum dalam sistemvisual. Sistem visual pada manusia memungkinkan untuk beradaptasi denganinformasi dari lingkungannya. Masalah utama dari persepsi visual ini tidak semata-mata apa yang dilihat manusia melalui retina. Namun lebih pada bagaimana menjelaskan persepsi dari apa yang benar-benar manusia lihat. ${ }^{11}$

Tujuan dari persepsi visual adalah untuk mengidentifikasi variasi pengalaman untuk memperoleh respon terhadap lingkungan terbangun melalui media stimulasi fotografi. Sistem visual pada manusia memungkinkan seseorang menyerap informasi dari lingkungannya. Dengan demikian, dari penjelasan mengenai persepsi visual tersebut dapat diperoleh kesimpulan bahwa adanya pengaruh dari gambar yang dilihat seseorang terhadap aspek psikologinya.

Dampak pengaruh yang ditimbulkan dari pesan semiotika melalui gambar yaitu:

1. Ketakutan

Ketakutan adalah bagian emosional dari pesan. Ketakutan yang dirasakanyaitu adanya rasa takut yang ditimbulkan setelah melihat pesan yangditampilkan pada gambar. Pesan yang berisikan penyakit atau ancamanakan lebih menimbulkan rasa takut yang semakin besar

${ }^{10}$ Sandra Krasovec, Desain Kemasan:Perencanaan Produk Yang Berhasil Mulai dari Konsep sampai Penjualan,Terjemahan Bob Sabran, (Jakarta:Erlangga, 2006), h. 81.

${ }^{11}{ }^{29}$ Rahmat jalaluddin, Psikologi Komunikasi, (Bandung:PT Remaja Rosdakarya, 2003), h.56. 
dampaknya kepadapembacanya.

2. Ancaman

Ancaman mengacu pada keparahan yang dirasakan dari pesan (Perceived Severity) misalnya merokok dapat menyebabkan penyakit kanker mulut,dan persepsi kerentanan dari pesan (Perceived Susceptibility) misalnya,saya atau perokok lainnya dapat terkena penyakit kanker mulut.

3. Keberhasilan yang dirasakan

Keberhasilan yang dirasakan terdiri dari keberhasilan tanggapan misalnya, dengan tidak berada di dekat orang yang sedangmerokok seseorang akan terhindar dari penyakit akibat asap merokok; dankeberhasilan sendiri misalnya, saya yakin bahwa saya bisatidak merokok atau tidak berada dekat dengan orang yang sedang merokokagar terhindar dari penyakit akibat asap rokok. ${ }^{12}$

Kampanye antirokok dengan menggunakan peringatan kesehatan bergambar memiliki dampak positif yang besar. Penelitian di beberapa negaramenunjukkan bahwa peringatan kesehatan bergambar lebih diperhatikan daripada hanya teks/tertulis, lebih efektif untuk pendidikan bagi perokok tentang resiko kesehatan akibat merokok dan untuk meningkatan pengetahuan perokok tentang resiko kesehatan akibat merokok serta adanya pengaruh terhadap sikap untuk tidak merokok.

1. Gambar

Pengaruh yang dapat ditimbulkan pesan semiotika pada kemasan rokok melalui:

Gmbar merupakansebuah representasi spasial dari fenomena obyek, adegan, atau lainnya.Dalam aspek ini, pemilihan gambar yang menakuti mengenai bahaya yang ditimbulkan dari rokok sangat berpengaruh terhadap pesan yang disampaikan pada kemasan rokok. ${ }^{13}$

Di mana terdapat 5 jenis gambar berwarna dan tulisan yang harus digunakan untuk kemasan rokok sesuai dengan Permenkes No 28 Tahun 2013, yaitu:
a. Gambar Kanker Mulut
b. Gambar orang merokok dengan asap yang membentuk tengkorak.
c. Gambar kanker tenggorokan
d. Gambar orang merokok dengan anak di dekatnya
e. Gambar paru-paru yang menghitam karena kanker dan tulisan

2. Pesan

Pesan adalah sebuah informasi tertulis yang memiliki tujuan tertentu. Setiap gambar pada kemasan rokok tersebut disertai pula tulisan sebagai berikut:
a. "Merokok Sebabkan Kanker Mulut"
b. "Merokok Membunuh Mu"
c. "Merokok Sebabkan Kanker Tenggorokan"
d. "Merokok Dekat Anak Berbahaya Bagi Mereka"
e. "Merokok Sebabkan Kanker Paru-Paru Dan Bronkitis Kronis"

\section{Warna}

Pesan semiotika dari gambar dapat juga mempengaruhi perokok ditinjau dari aspek kognitif. Menurut Mann dalam buku Syaifudin bahwa " aspek kognitif mencakup faktor pengetahuan, persepsi dan kepercayaan ". ${ }^{14}$ Maka pengetahuan perokok yang didapat dari melihat gambar pada kemasan rokok mengenai penyakit-penyakit yang disebakan oleh rokok menjadi salah satu indicator yang mempengaruhi sikap perokok terhadap rokok.

${ }^{12}$ Ernest Caldwell, Berhenti Merokok, (Yogyakarta:Pustaka Seluler, 2009), h. 83

13 Alex Sobur, Semiotika Komunikasi, (Bandung: PT Remaja Rosdakarya, 2004), h. 244

${ }^{14}$ Syaifudin, Komunikasi Persuasif, (Bandung:PT Rosdakarya, 1996), h. 82. 
Indikator lainnya yaitu dari persepsi yang didapat perokok setelah melihat gambar pada kemasan rokok.

\section{METODOLOGI PENELITIAN}

Jenis Penelitian

Dalam penelitian ini penulis menggunakan jenis penelitian deskriptif yaitu penelitian yang berusaha mendeskripsikan suatu gejala, peristiwa, kejadian yang terjadi saat sekarang. Penelitian deskriptif memusatkan perhatian kepada masalah- masalah aktual sebagaimana adanya pada saat penelitian berlangsung. Melalui penelitian deskriptif, peneliti berusaha mendeskripsikan peristiwa dan kejadian yang menjadi pusat perhatian tanpa memberikan perlakukan khusus terhadap peristiwa tersebut. Penelitian ini dilaksanakan dengan menggunakan metode ilmiah penelitian dilaksanakan berdasarkan teori-teori, prinsip-prinsip, serta asumsi-asumsi dasar ilmu pengetahuan dengan menggunakan penalaran deduktif serta prosedur dan teknik sistematik. ${ }^{15}$

\section{Lokasi dan Subjek Penelitian}

Lokasi penelitian yang peneliti gunakan adalah Gampong Alue Tho Kecamatan Seunagan Kabupaten Nagan Raya. Alasan penulis membuat penelitian di Gampong tersebut dikarenakan banyak masyarakat disana hampir semua kaum laki-laki sebagai perokok aktif.

Adapun subjek penelitian adalah masyarakat Gampong Alue Tho sebagai perokok aktif untuk menjadi objek penelitian.

\section{Populasi dan Sampel}

a. Populasi

Menurut Nawawi Populasi adalah "keseluruhan subyek yang terdiri dari manusia dan benda-benda, hewan tumbuhan, gejala-gejala atau peristiwa-peristiwa yang terjadi sebagai sumber". Berdasarkan batasan tadi, maka dapat ditetapkan bahwa populasi penelitian ini, di khususkan pada masyarakat perokok yang dijadikan populasi adalah seluruh masyarakat perokok aktif yang ada di Gampong Alue Tho yaitu 300 orang.

b. Sampel

Dalam penelitian ini menggunakan $10 \%$ sampel dari jumlah populasi yaitu, 30 orang yang mewakili dari jumlah populasi 300 orang perokok aktif di Gampong Alue Tho Kecamatan Seunagan Kabupaten Nagan Raya.

Teknik Pengumpulan Data

Beberapa teknik pengumpulan data dalam penelitian kuantitatif, yaitu:

1. Observasi

Beberapa informasi yang diperoleh dari hasil observasi adalah ruang (tempat), pelaku, kegiatan, objek, perbuatan, kejadian atau peristiwa, waktu, dan perasaan.

2. Angket (questionnaire)

"Dalam hal ini penulis menggunakan angket sebagai alat untuk mendapatkan informasi dan angket yang diedarkan dalam penelitian ini adalah angket tertutup.

3. Dokumentasi

Metode dokumentasi bertujuan untuk mendapatkan informasi yang mendukung analisis dan interpretasi data.

Teknik Analisis Data

${ }^{15}$ Bungin B. Penelitian Kualitatif. (Jakarta :Prenada Media Group 2007), h.201 
Metode yang digunakan adalah metode survei dengan pendekatan kuantitatif, artinya setiap data yang terhimpun dan tersusun secara sistematis, untuk kemudian dipelajari dan dianalisa secara deskriptif. ${ }^{16}$

Setelah data dikumpulkan selanjutnya penulis melakukan analisis data mulai dengan mengadakan penyelesaian dan kemudian didistribusikan kedalam sub-sub bab, kemudian diolah dan dianalisis secara kuantitatif. Semua data yang terkumpulkan melalui angket ditabulasikan dalam bentuk tabel dan tafsiran presentase secara sederhana sebagaimana rumus berikut dari Nana Sudjana

\section{1. $P=X 100 \%$}

Keterangan: $\quad \mathrm{P}:$ Harga presentase dicari

$$
\begin{aligned}
& \mathrm{f}: \text { Frekuensi yang muncul } \bar{n} \\
& \mathrm{n} \text { : Jumlah sampel }
\end{aligned}
$$

\section{HASIL PENELITIAN}

Gambaran Umum Lokasi Penelitian

Adapun penelitian di lakukan pada gampong Alue Tho yang terdapat pada Kecamatan Seunagan Kabupaten Nagan Raya. ${ }^{17}$ Gampong Alue Tho terdiri dari empat dusun yaitu dusun Alue Bakti, dusun Ujong Bale, dusun Ule Umeung, dan dusun Dayah. Semua Gampong yang berbatasan dengan Gampong Alue Tho berada dalam Gampong Alue Tho Kecamatan Seunagan dan Seunagan Kabupaten Nagan Raya. ${ }^{18}$

Demografi dibawah ini:

Demografi berdasarkan jumlah penduduk secara umum dapat dilihat pada tabel

Tabel. 4.1 jumlah penduduk

\begin{tabular}{|c|l|c|c|c|c|}
\hline \multirow{2}{*}{ No } & \multirow{2}{*}{ Dusun } & \multirow{2}{*}{$\begin{array}{c}\text { Jumlah } \\
\text { KK }\end{array}$} & \multicolumn{2}{|c|}{ Jumlah Jiwa } & \multirow{2}{*}{ Total Jiwa } \\
\cline { 4 - 5 } & & 109 & 185 & 177 & 362 \\
\hline 1 & Alue Bakti & 65 & 120 & 128 & 248 \\
\hline 2 & Ujong Bale & 24 & 45 & 42 & 87 \\
\hline 3 & Ule Umeung & 51 & 85 & 84 & 169 \\
\hline 4 & Dayah & 54 & $\mathbf{4 3 5}$ & $\mathbf{4 3 1}$ & $\mathbf{8 6 6}$ \\
\hline \multicolumn{2}{|l|}{ Jumlah } & $\mathbf{2 4 9}$ & \multicolumn{2}{|c}{} \\
\hline
\end{tabular}

Jumlah jiwa laki-laki dari tabel diatas 435 orang, kemunculan angka perokok aktif di gampong alue tho mulai dari anak-anak remaja (18 tahun), dewasa(20-30 tahun) hingga yang sudah berumur 50 tahun ke atas yaitu 300 orang dan perokok aktif.

Pemahaman Makna Pesan Semiotika

Media gambar atau visual mampu mengkomunikasikan pesan dengan cepat dan berkesan. Sebuah gambar bila dapat memilihnya bisa memiliki nilai yang sama dengan ribuan kata , juga secara individual mampu memikat perhatian. Visualisasi adalah cara atau sarana yang paling tepat untuk membuat sesuatu yang abstrak menjadi jelas. Penampilan secara visual selalu mampu untuk menarik emosi pembaca dan dapat memutuskan suatu problema untuk

${ }^{16}$ Tukiran Taniredjadan Hidayati Mustafidah,,Penelitia Kuantitatif...h. 41-45

${ }^{17}$ Dokumen Kantor Geuchik Gampong Alue Tho Kecamatan Seunagan Kabupaten Nagan Raya

${ }^{18}$ Dokumen Sejarah Gampong Alue Tho 
kemudian mengkhayalkan pada kejadian yang sebenarnya. Informasi bergambar lebih disukai dibandingkan dengan informasi tertulis karena menatap gambar jauh lebih mudah dan sederhana.

Gambar-gambar pada kemasan rokok memiliki makna yang signifikan. Dengan kemunculan gambar diharapkan mampu mempengaruhi para perokok untuk berhenti merokok sebagai wujud peduli terhadap kesehatan dirinya sendiri. Gambar-gambar tersebut tampak sangat mengerikan, langkah ini diambil untuk menggantikanperingatan bahaya merokok yang terdahulu yang berupa tulisan.Sebaiknya pemerintah memberikan peraturan bagi perokok dengan memberikansanksi yang tegas yang berupa denda maupun hukuman. Atau pemerintah memberikan solusi bagi perokok untuk mengurangi konsumsi rokok dengan melalui pengobatan bagi pecandu rokok berat.

Label gambar yang tercantum pada setiap kemasan rokok sangat jelas karena ditempatkan bagian depan atas dan belakang atas. Meskipun gambar tersebut sangat jelas walaupun tidak diperhatikan namun ada sebagian perokok tidak memperhatikan gambar tersebut disebakan para perokok hanya mengambil batang rokok yang tersedia dalam kemasan.

Setelah memperhatikan gambar pada setiap kemasan tentu ada rasa yang ditimbulkan saat pertama kali melihat gambar itu, tentu para perokok merasa takut bahkan khawatir dengan label peringatan yang begitu mengerikan, seperti gambar kanker mulut, menampilkan mulut yang telah bengkak kemudian gambar jantung yang hitam akibat bahaya zat nikotin yang terkandung pada setiap batang. Untuk melihat bagaimana perasaan ketika pertama sekali melihat gambar yang mengerikan pada kemasan rokok, oleh masyarakat perokok aktif di Gampong Alue Tho dapat dilihat pada tabel dibawah ini:

Pemahaman label yang jelas akan ada sesuatu hal yang akan ditangkap oleh pikiran yang akan mempengaruhi sudut pandang sesorang. Pesan yang disampaikan lewat gambar pada setiap kemasan rokok sebagai peringatan bahwa merokok itu dapat mengangu kesehatan dan dapat menimbulkan berbagai macam penyakit seperti kanker otak, paru-paru dan lain sebagainya. Namun para perokok terkadang hanya menganggap sebuah gambar hanya sebatas bentuk peringatan saja. Padahal bukan hanya sebagai peringatan saja tetapi bisa merusak kesehatan apabila terus menerus menghisap rokok. Disisi lain ada juga masyarakat perokok mengangap gambar tersebut hanya sebatas gambar yang tidak memiliki makna yang terkandung didalamnya. Berikut ini adalah presentase yang telah peneliti telah lakukan terhadap para perokok dalam tabel dibawah ini:

Dari keseluruhan gambar semuanya berbentuk peringatan, tergantung masyarakat yang memahami makna tersebut. Namun adakala perokok menganggap hanya sebatas gambar yang tidak memiliki makna apapun.

\section{Pandangan Islam Tentang Rokok}

Istilah rokok sudah dikenal dan membudaya diberbagai belahan dunia islam. Sejak itulah sekarang hukum rokok gencar dibahas oleh para ulama diberbagai negeri, baik secara kolektif maupun pribadi. Perbedaan pendapat diantara mereka mengenai hukum rokok tidak dapat dihindari dan berakhir kontroversi. Sebagian diantara mereka memfatwakan mubah alias boleh, sebagian berfatwa makruh, sedangkan lainnya lebih memfatwakan haram.

Namun dalam hal ini keempat mazhab yaitu Syafi'i, Maliki, Hambali dan Hanafi dari ulama yang terkemuka yang mengikuti setiap mazhab mengharamkan mengenai rokok. salah satunya Abu Zaid dari mazhab Maliki mengatakan sesungguhnya yang menjadi sandaran tanpa ada yang menyelisihi, yang menjadi rujukan untuk kebaikan agama dan dunia, serta wajib diserukan keseluruh penjuru negeri islam bahwa rokok haram digunakan, karena mayoritas ilmuwan menyatakan bahwa rokok mengakibatkan kemalasan dan kelemahan, dan rokok 
mempunyai segi kesamaan dengan khamar dalam hal memabukkan. ${ }^{19}$

Akan tetapi persoalan akan lain ketika merokok itu dihukumi haram, akan muncul pro dari pihak tertentu dan muncul pula kontra serta penolakan dari pihak- pihak yang tidak sepaham. Dalam tinjauan fiqh terdapat beberapa pendapat dengan berbagai argumen yang bertolak belakang. Pada dasarnya terdapat nash yang menjadi patokan umum, yakni larangan melakukan segala sesuatu yang dapat membawa kerusakan, kemudaratan atau kemafsadatan sebagaimana termaktub didalam Al-Quran Surat Al-Baqarah ayat 195:

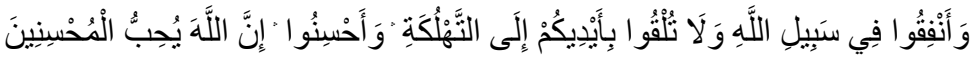

Dan janganlah kamu menjatuhkan dirimu sendiri kedalam kebinasaan, dan berbuat baiklah, karena sesungguhnya Allah menyukai orang-orang yang berbuat baik.

Dari ayat tersebut ulama sepakat mengenai segala sesuatu yang membawa mudarat adalah haram. Akan tetapi yang menjadi persoalan adalah apakah merokok itu membawa mudarat atau tidak, dan terdapat manfaat atau tidak. Dalam hal ini tercetus persepsi yang berbeda dalam meneliti dan mencermati substansi rokok dari kemaslahatan dan kemafsadatan. Jika semua sepakat bahwa merokok tidak membawa mudarat maka semua akan sepakat dengan hukum mubah atau makruh, demikian juga apabila semua sepakat bahwa merokok membawa mudarat besar, maka akan sepakat pula dengan hukum haram.

hukum:

Beberapa pendapat itu serta argumennya dapat diklasifikasikan menjadi tiga macam

1. Hukum mubah atau boleh karena rokok dipandang tidak membawa mudarat, secara tegas dapat dinyatakan bahwa hakikat rokok bukanlah benda yang memabukkan.

2. Hukum makruh karena rokok membawa mudarat relatif kecil yang tidak signifikan untuk dijadikan dasar hukum haram.

3. Hukum haram karena rokok secara mutlak banyak dipandang membawa banyak mudarat. Berdasarkan informasi mengenai hasil penelitian medis bahwa rokok dapat menyebabkan berbagai penyakit dalam seperti kanker, paru-paru dan lainnya setelah sekian lama membiasakannya.

Ketiga hukum tersebut dapat berlaku secara general, dalam arti mubah, makruh dan haram itu bagi siapapun orangnya. Namun bisa jadi tiga macam hukum tersebut berlaku secara personal, dengan pengertian setiap orang akan terkena hukum yang berbeda sesuai dengan apa yang diakibatkannya, baik terkait kondisi personnya atau kuantitas yang dikonsumsinya.

\section{Pengaruh Pesan Semiotika Melalui Gambar Terhadap Perokok}

Sesuai peraturan menteri kesehatan republik indonesia nomor 28 tahun 2013, setidaknya ada lima gambar yang dicantumkan dibagian wajah kemasan rokok. Kelima gambar tesebut wajib itu bertema merokok menyebabkan kanker mulut, merokok membunuhmu, merokok sebabkan kanker tenggorokan, merokok dekat anak berbahaya bagi mereka, serta merokok sebabkan kanker paru-paru dan kronis dan bronkitis.

Dari gambar tersebut para perokok akan beranggapan bahwa merokok dapat menimbulkan berbagai macam penyakit yang berbahaya. Setelah melihat gambar pada kemasan rokok tersebut, perokok akan percaya bahwa rokok dapat menimbulkan penyakit seperti padayang terdapat pada gambar kemasan rokok dan memiliki pengaruh, namun ada juga perokok yang tidak terpengaruh.

Dalam proses komunikasi, ada tiga unsur yang sangat penting untuk terjadinya sebuah komunikasi, yaitu komunikator pesan dan komunikan. Dianggap komunikator yang baik apabila

\footnotetext{
${ }^{19}$ http// Hukum Merokok Menurut Mazhab, Islam kompas.com, diakses 23 Februari 2017
} 
pesan yang disampaikan kepada komunikan dapat tersalurkan dengan baik, dan komunikan memahami maksud dari pesan tersebut. Begitu juga dalam penyampaian pesan gambar pada kemasan rokok yang memiliki makna peringatan dan merusak kesehatan.

Meskipun pesan gambar tersebut sangat mudah dipahami namun ada juga sebagian masyarakat yang kurang memahami makna pesan tersebut. Namun ada juga responsen yang kurang memahami dari makna gambar tersebut, dari penelitian yang telah peneliti lakukan yang kurang memahami ini adalah kalangan orang tua yang tidak begitu mengenal penyakit kronis.

Apabila sebuah pesan dapat tersampaikan dengan baik kepada komunikan, tentu saja akan mendapatkan efek yang akan mengubah persepsi seseorang. Begitu juga dalam hal pesan gambar pada kemasan rokok, jika para perokok memahami maksud dari pesan itu dan mengerti terhadap bahaya yang ditimbulkan dari rokok tersebut tentu akan mengubah pandangan mengenai rokok. Dalam hal ini para perokok akan mempertimbangkan untuk menghisap rokok.

Pemberhentian bisa dilakukan oleh para perokok setelah mempertimbangkan hal-hal yang buruk yang akan terjadi dimasa yang akan datang. Melalui pesan semiotika pada isi gambar sangat mudah dipahami dengan menampilkan berbagai macam penyakit. Upaya pemerintah membuat setiap kemasan rokok dibubuhi gambar peringatan, diharapkan mampu menyadarkan masyarakat untuk mengurangi bahkan berhenti merokok.

Kecanduan terhadap zat nikotin ini sudah menjadi kebiasaan yang susah untuk ditinggalkan, meskipun demikian rasa ingin mengurangi adalah hal yang tepat dilakukan. Adanya rasa ingin mengurangi tidak menutup kemungkinan suatu saat akan berhenti merokok. Dalam hal ini masih ada masyarakat yang tidak mau berhenti merokok walaupun sudah ada peringatan, mereka hanya menganggap itu semua tidak benar kenyataannya sudah bertahuntahun merokok tetapi tidak terkena penyakit kronis tersebut. Tanpa mereka sadari gejala penyakit awal sudah dirasakan seperti batuk-batuk,penyakit jantung atau hal-hal lainnya.

Penyakit-penyakit kronis yang ditampilkan pada kemasan rokok begitu sangat mengerikan, tetapi para perokok masih berfikir itu semua tidak akan terjadi, dan kalaupun itu terjadi sudah menjadi resiko mereka sebagai pecandu, berikut ini pertanyaan mengenai pesan dari gambar sesuai dengan efek yang dirasakan setelah mengkomsumsi rokok, dan hasilnya pada tabel dibawah ini:

\section{Efek Dari Pesan Gambar Di Kemasan Rokok}

Dalam proses komunikasi pesan yang disampaikan dapat dipahami dengan jelas maka akan menimbulkan efek yang dirasakan oleh komunikan. Pengaruh ialah perbedaan antara apa yang difikirkan, dirasakan, dan dilakukan oleh penerima pesan sebelum dan sesudah menerima pesan. Pengaruh tersebut bisa mencakup banyak hal, tergantung dari komunikator menyampaikan pesan kepada komunikan.

Komunikasi bersifat efektif apabila pesan tersebut menimbulkan efek, efek tersebut berupa perhatian yang selanjutnya menjadi berupa tata kelakuan atau tingkah laku, sesuai dengan pesan yang disampaikan. Begitu juga dalam pesan gambar pada kemasan rokok yang akan menimbulkan efek terhadap para perokok jika pesannya dipahami dengan jelas. Berikut ini beberapa pertanyaan yang telah dilakukan penelitian terhadap para perokok, yang mengenai efek yang dirasakan baik dari segi tingkah laku, ataupun perhatian.

Upaya pemerintah telah melakukan berbagai macam cara agar masyarakat menumbuhkan kesadaran agar berhenti merokok, mulai dari pemasangan spanduk-spanduk, poster, himbauan hingga memasang gambar mengerikan pada kemasan rokok. Tanpa ada dukungan dari masyarakat semua ini tidak akan berhasil. Berikut ini mengenai kesetujuan masyarakat terhadap gambar yang dipasangkan pada kemasan rokok sebagai upaya untuk mengurangi dan menyadarkan perokok terhadap bahaya zat nikotin yang terdapat dalam batang rokok. 
Upaya dalam penanggulangan untuk berhenti merokok telah dilakukan berbagai cara diharapkan menumbuhkan kesadaran masyarakat terhadap efek yang akan ditimbulkan. Walaupun hasilnya belum maksimal tingkat kepedulian pemerintah terhadap masyarakat telah banyak dilakukan.

\section{PENUTUP}

Rokok adalah silinder kertas yang berisi daun tembakau yang didalamnya telah dicampur zat nikotin apabila dihisap akan merusak kesehatan. Namun dalam hal ini tingkat kecanduan terhadap rokok semakin meningkat pada kalangan masyarakat sekarang ini. Upaya pemerintah dalam penanggulangan telah dilakukan berbagai cara mulai dari peringatan tulisan hingga ditampilkan gambar-gambar pada setiap kemasan.

Gambar tersebut menjelaskan berbagai penyakit yang diderita yang bertema merokok menyebabkan kanker mulut, merokok membunuhmu, merokok sebabkan kanker tenggorokan, bahaya merokok didekat anak-anak, serta menyebabkan penyakit kronis dan bronkitis. Pemaknaan pesan lewat gambar lebih efektif dipahami dibandingkan dengan kata-kata lewat tulisan. Melalui pesan semiotika yang disampaikan lewat gambar, diharapkan masyarakat terpengaruh untuk mengurangi, dan menumbuhkan kesadaran agar berhenti merokok demi kesehatan.Dan memahami bahwa zat nikotin yang terus dihisap akan menimbulkan berbagai macam penyakit yang menyebabkan kematian. Meskipun pemaknaan gambar dapat dipahami, merupakan hal yang wajar jika ada masyarakat yang terpengaruh dari gambar tersebut. Namun ada juga masyarakat yang tidak terpengaruh dari apa yang disampaikan pesan gambar, karena mengangap hanya sebatas menakuti saja

\section{DAFTAR PUSTAKA}

Bungin, Burhan, 2007. Penelitian Kualitatif. Prenada Media Group. Caldwell, Ernest. Jakarta.

Caldwell, Ernest. 2009. Berhenti Merokok: Pustaka Seluler, 2009. Yogyakarta.

Krasovec, Sandra. 2006. Desain Kemasan:Perencanaan Produk Yang Berhasil Mulai dari Konsep sampai Penjualan,Terjemahan Bob Sabran, Erlangga. Jakarta.

Mudjiyanto, Bambang. 2013. Semiotika Dalam Metode Penelitian Komunikasi Semiotic, Balai Besar Pengkajian dan Pengembangan Komunikasi dan Informatika. Makassar.

Muhammad, Jaya. 2009 Pembunuh Berbahaya Itu Bernama Rokok, Rizma'. Jakarta.

Noth, Winfriend. 1995. Handbook Of Semiotic, dikutip oleh Sumbo Tinarbuko, Indiana University Press. Indianapolis.

Rakhmat, Jalaludin 1994. Psikologi Komunikasi. Remaja Rosdakarya. Bandung.

Syaifudin. 1996. Komunikasi Persuasif, Remaja Rosdakarya. Bandung.

Subur, Alex, 1998. Semiotika Komunikasi, Rosda. Jakarta.

Supriyono, Rachmat.2010. Desain Komunikasi Visual, Balai Pustaka. Yogyakarta.

Syaifudin. 1996. Komunikasi Persuasif, Remaja Rosdakarya. Bandung. 
Tinarbuko, Sumbo. 2008. Memahami Tanda, Kode, Dan Makna Iklan Layanan Masyarakat, Bandung: ITB Bandung, 1998. dan, Semiotika Komunikasi Visual. Jalasutra. Yogyakarta.

Tukiram, dan dkk, 2010. Penelitian Kuantitatif Sebuah Pengantar. Alfabeta. Bandung.

Website Pp_No._19_Th_2003. http://www.litbang.depkes.go.id. 